\title{
ŚWIATŁO WIELKIEGO MIASTA W LIRYCE MŁODEJ POLSKI
}

\author{
URSZULA M. PILCH*
}

\begin{abstract}
Duch mój zamieszkał wyludnione miasta i widmem nędzy przepala swe oczy duch mój gdzieś w dale bezimienne kroczy, jak pogrzeb, wynoszący trędowatych z miasta.

Biją mi głucho popękane dzwony i anioł ciemny prowadzi za sobą i jak biczownik, okryty żałobą, płaczę - a w łzach mych biją nieszczęść dzwony.

W zmarzłej dolinie Cienia śmierci, gdzie gwiazd migocą sarkofagi, buduję sobie dół - i nagi z płomieniem schodzę w cienie śmierci ${ }^{1}$.
\end{abstract}

Zacytowany utwór pochodzi z jednego z najlepszych i zarazem najbardziej wyrazistych tomów poetyckich Młodej Polski, a mianowicie z tomu W mroku gwiazd Tadeusza Micińskiego. Niezależnie od swej wyjątkowości wiersz ten odzwierciedla stosunek całej właściwie epoki do przestrzeni miejskich ${ }^{2}$. Najmocniejszy i zarazem najlepiej znany jego przejaw odnaleźć możemy w powieściach, by wspomnieć tylko dla przykładu dzieła Berenta, Reymonta czy Żeromskie$\mathrm{go}^{3}$. Miasto powiązane zatem bywa $\mathrm{z}$ poczuciem uwikłania, uwięzienia, stagnacji. Równocześnie staje się przestrzenią fascynującą, uzależniającą i zarazem

* Urszula M. Pilch - dr, adiunkt, Wydział Polonistyki UJ.

1 T. Mi c ińs ki, Wybór poezji, wstęp i oprac. W. Gutowski (Biblioteka Polska), Kraków 1999, s. 130.

${ }^{2}$ Por. W. Gutowski, Symbolika urbanistyczna $w$ literaturze polskiego modernizmu [w:] te goż, Mit - Eros - Sacrum. Sytuacje młodopolskie, Bydgoszcz 1999. Por. również A. Czab an ow ska-Wróbe 1, Spadkobiercy i turyści. O „młodszych braciach” Staffa i Leśmiana [w:] Złotnik i śpiewak. Poezja Leopolda Staffa i Bolesława Leśmiana w kręgu modernizmu (Modernizm w Polsce, nr 29), Kraków 2009; W. Gu tow ski, Z próżni nieba ku religii życia. Motywy chrześcijańskie w literaturze Młodej Polski, Kraków 2000, np. s. 354-355. Zob. także z perspektywy ogólnej: E. Ry bi ck a, Modernizowanie miasta. Zarys problematyki urbanistycznej w nowoczesnej literaturze polskiej, Kraków 2000. Podaję tylko przykłady.

${ }^{3}$ Bibliografię podaje E. Ry bi ck a, dz. cyt., s. 28. Autorka wymienia prace M. Popiel, W. Gutowskiego, I. Maciejewskiej. 
doświadczaną poprzez flânerie. Spójnie i nierozerwalnie łączy w sobie cechy dynamicznego witalizmu z przerażającym i uwodzicielskim zarazem rozkładem ${ }^{4}$. Wykształca się bowiem wieloaspektowy i wielowektorowy mit miasta, który, jak zauważają badacze, zdominowany jest przez mit antyurbanistyczny. Nie chodzi tu tylko o antyurbanizm, znajdujący swój przejaw w opozycyjnym zestawianiu obcości i swojskości, ani o retorykę antycywilizacyjną. Na tego typu perspektywę nakłada się także uczynienie z problematyki urbanistycznej zagadnienia literackiego. Brzozowski krytykuje „zmityzowane postawy wobec miasta"5; Przesmycki „krytykuje [...] miasto z perspektywy jego zagrożeń wobec sztuki”, Irzykowski znosi opozycję wsi i miasta, przenosząc akcent z tematu na technikę literacką ${ }^{7}$.

Pojawia się wreszcie - najbardziej mnie interesująca - kwestia wyrażania miejskiego doświadczenia ${ }^{8}$. Właśnie w liryce najwyraźniej zarysowuje się problem poszukiwania języka do ujęcia przestrzeni miejskiej. Nieodłącznym punktem odniesienia staje się tu podmiot liryczny, który owo miasto rozpoznaje w sposób skrajnie zsubiektywizowany. Kwestie te kondensują się w sposobach ujmowania światła9.

Przywołany wiersz Micińskiego można potraktować jako szczególnej wagi ogniwo w niniejszej refleksji. Wyludnione miasto staje się tu znakiem śmierci absolutnej. Podmiot przyporządkowujący swego ducha takiej właśnie przestrzeni wskazuje równocześnie na dotykającą jego samego destrukcję:

Duch mój zamieszkał wyludnione miasta i widmem nędzy przepala swe oczy -

${ }^{4} \mathrm{O}$ młodopolskiej fascynacji rozkładem zob. przede wszystkim W. Gutowski, Miłość śmierci i energia rozkładu. O młodopolskiej wyobraźni nekrofilskiej [w:] te g o ż, Konstelacja Przybyszewskiego, Toruń 2008.

${ }^{5}$ E. Rybicka, dz. cyt., s. 84 .

6 Tamże, s. 84.

7 Tamże, s. 87.

${ }^{8}$ Tamże.

${ }^{9} \mathrm{O}$ znaczeniu światła w tworzeniu przestrzeni miejskiej i o powiązanych z nim sposobach doświadczania miasta por. (w innym kontekście): M. B erman, Płomienie domowego ogniska. Znaki na Times Square; Nostalgia na Times Square; A. Re jn iak-Maje w ska, Światta wielkiego miasta. Estetyka komercji, nowoczesny witalizm i ponowoczesna tęsknota [w:] Rekonfiguracje modernizmu. Nowoczesność i kultura popularna, red. T. Maje wski, (Popkultura i Media), Warszawa 2009; E. Rew e rs, Ontologia światła: w stronę elektropolis [w:] Post-polis. Wstęp do filozofii ponowoczesnego miasta (Horyzonty Nowoczesności, nr 41), Kraków 2005. Ze sposobem konstruowania symboliki światła w młodopolskiej liryce wiąże się także niewątpliwie specyfika nastroju nocy, por. M. Podraza-Kwi at k ow s k a, „Bacz o człowiecze, co głęboka noc rzecze”. $Z$ rozważań nad literackim przeżywaniem nocy [w:] Literatura - punkty widzenia - światopoglqdy. Prace ofiarowane Marcie Wyce, red. D. Kozicka, M. Urbanowski, Kraków 2008, por. także W. Gu tow sk i, Młodopolskie dialogi (z) noca [w tomie:] Noc. Symbol-temat-metafora, t. 2, Noce polskie, noce niemieckie, pod red. J. Ławskiego, K. Korotkicha, M. Bajki, Białystok 2012. 
Przepalanie oczu przyjmuje funkcję masochistycznego gestu, który pogrąża podmiot w ciemności zupełnej, o znamionach nie tylko poznawczych, ale też ontologicznych ${ }^{10}$. Moment wniknięcia i identyfikacji z przestrzenią opuszczonego czy wymarłego miasta staje się pierwszym etapem wkraczania w spatium zarówno śmierci indywidulanej, jak i tej totalnej. Wyobrażenia miasta w twórczości Micińskiego ${ }^{11}$ najczęściej powiązane są z wizjami niemal apokaliptycznymi, by wspomnieć chociażby fragment Xiędza Fausta poświęcony trzęsieniu ziemi w Messynie ${ }^{12}$. Nawet zatem tam, gdzie pojawia się jakaś forma światła, współistnieje ona z destrukcyjnym ogniem i okazuje się waloryzowana negatywnie. Taka sytuacja ma miejsce w poemacie prozą Różany obłok:

Z gór mówię białych przy zachodzącym słońcu.

Mrocznieją głazy olbrzymie, idą na wasz gród.

Nie oszczędzą sadów ni minaretów.

Złote wieżyce legną w ruinach, na dywanach smyrneńskich pokrwawią się głowy.

Nałożnice w plusku fontann usłyszą spoza wysokich ścian ogrodu huk ciężki zstępujących olbrzymów.

Miasto, jak garść brylantów migocąca w marmurowej misie, rozbłyśnie tysiącami ogni tych, co zbudzeni będą pytać i zmilkną ${ }^{13}$.

Nadchodząca zagłada współgra z zachodem słońca (a więc z zapadającą ciemnością). Proroctwo głoszone przez podmiot ${ }^{14}$ rysuje wizję zniszczenia miasta, a w nim wszystkiego tego, co wiąże się z szeroko pojmowaną cywilizacją. Po stronie zagłady stoi bowiem nie tylko mrok, ale stoją także telluryczne, chtoniczne głazy. Światło okazuje się tu tylko krótkim, chwilowym, przedśmiertnym zrywem, połączonym w dodatku z ogniem jako symbolem zniszczenia. Panorama rozświetlonego miasta porównywana do garści brylantów (z całym jej bagażem symbolicznym) nie funkcjonuje jednak jako znak rozwoju cywilizacyjnego, ale przyjmuje znaczenia bez porównania bardziej ogólne. Jasność staje się tu (zgodnie z konwencją) znakiem poznania, a raczej dążenia do poznania. Niepo-

${ }^{10}$ Por. U. M. Pil ch, Oczy i wzrok [w:] te jże, Kto jestem? O podmiocie w poetyckim dwugłosie. Słowacki-Miciński, Kraków 2010, s. 163.

${ }^{11}$ Zob. W. Gutow s ki, Burzyciel świqtyń i budowniczy nadgwiezdnych miast. O symbolice architektonicznej w twórczości Tadeusza Micińskiego [w:] te go ż, Wprowadzenie do Xięgi tajemnej. Studia o twórczości Tadeusza Micińskiego, Bydgoszcz 2002; M. B a jko, Miasta potępienie, czyli Tadeusz Miciński wśród miejskich przestrzeni [w:] Edukacja dla przyszłości, tom V, red. J. F. Nosowicz, J. Gorbacz-Pazera, Białystok 2008.

${ }^{12}$ Por. uwagi W. Gut ow sk i e go [w:] te g o ż, Z próżni nieba..., dz. cyt., s. 365. Zob. także te g oż, Synteza - niedokonanie - „skok w przyszłość”... O „Xiędzu Fauście” Tadeusza Micińskiego [w:] T. Miciń ski, Xiqdz Faust, oprac. tekstu, przypisy i posłowie W. Gutowski, Kraków 2008.

${ }^{13}$ T. M i c iń sk i, Poematy prozq, oprac. W. Gutowski (Biblioteka Poezji Młodej Polski), Kraków 1985, s. 155.

${ }^{14}$ W. Gut ow ski, Wstęp [w:] T. Mi cińs ki, Poematy proza, dz. cyt., s. 24. 
kój niewiedzy zostaje natychmiast tragicznie wyciszony w chwili zagłady, która jest przecież zagładą z ognia.

Teksty Micińskiego są - pod wieloma względami - wyjątkowe na tle Młodej Polski. Nie ma chociażby w jego poezji właściwego krajobrazu miejskiego, $\mathrm{z}$ tego też powodu nie mamy tu de facto do czynienia z oświetleniem miejskim. Niemniej jednak uzmysławiają one nie tylko widoczną w tej poezji tendencję do budowania obrazów destrukcji, ale także tendencję ogólną do postrzegania miasta jako przestrzeni niepokoju. Z drobnymi, aczkolwiek niezwykle istotnymi wyjątkami, dominuje reguła, że światło miejskie podważa - pod każdym, także ontologicznym względem - poczucie nie tyle bezpieczeństwa, ile stałości podmiotu w ogóle.

Unicestwienie podmiotu lirycznego wobec światła latarni da się dostrzec w jednym z bardziej znamiennych tekstów, a mianowicie w utworze Ludwika Szczepańskiego z cyklu $Z$ sonetów wiedeńskich zatytułowanym Oczy. Ringstrasse w noc zimowq. Zwyczajna sytuacja liryczna - widok latarni miejskich w nocnej mgle przy wiedeńskiej Ringstrasse - stanowi podstawę jednego z najlepszych utworów Szczepańskiego.

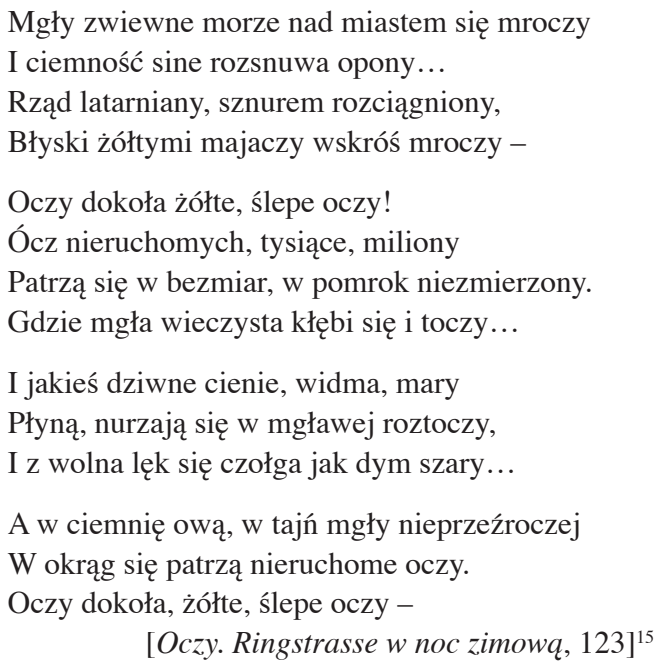

Oparcie kompozycji sonetu na przeciwstawieniu ciemności i żółtego blasku latarni przyczynia się do wywołania efektu absolutnego osaczenia podmiotu. Ta opozycja zasadza się przede wszystkim na obecności i braku światła; przyczynia się do spotęgowania narastającego niepokoju. Wyizolowany pojedynczy podmiot zostaje bowiem skonfrontowany $\mathrm{z}$ - pozbawionym jakiegokolwiek pozytywnego

${ }^{15}$ L. S zc ze pańs ki, Poezje wybrane, oprac. A. Nowakowski (Biblioteka Poezji Młodej Polski), Kraków 1993. Przy cytatach z utworów Szczepańskiego liczba w nawiasie oznacza numer strony. 
elementu - pejzażem, który postrzega jako agresywnie ofensywny. Poczucie bycia obserwowanym jest tym bardziej przerażające, że z jednej strony patrzące oczy są paradoksalnie ślepe, z drugiej ich wzrok podważa istnienie samego podmiotu. „Ja” liryczne pomimo poczucia własnej jednostkowości zostaje utożsamione (czy raczej wcielone, zespolone) z mrokiem: „Patrzą się w bezmiar, w pomrok niezmierzony". Tym większy jest więc tragizm całej sytuacji lirycznej, w której światło latarni powoduje poczucie osobności, jednostkowości ,ja”, ale - co za tym idzie - powoduje równocześnie świadomość wykluczenia. Podmiot natomiast, dla którego owa pierwotna jednostkowość jest niewątpliwie atrakcyjna, zostaje skonfrontowany z koniecznością podważenia swojego istnienia w ogóle. Tożsamość podmiotu konstytuowana jest zatem tylko i wyłącznie przez odczuwany strach; przenicowane przez światło latarni ,ja” znika ${ }^{16}$.

Wniknięcie światła latarni w psychiczną i cielesną tkankę podmiotu rozbija zatem jego istnienie. Tego typu sytuacja zagrożenia wykreowana została we fragmencie prozy poetyckiej Jana Wroczyńskiego zatytułowanej Buddha. Bohater, tak jak podmiot u Szczepańskiego, widzi latarnie jako przerażające oczy:

Oczy nieruchomo wlepił w jakieś dalekie latarnie, co jakby jaskrawe, ostre, zdecydowane chryzantemy - gwiazdy żółte, skamieniałe nieruchomie trwały na niewidzialnych, żelaznych łodygach okolone nimbami tęczowej mgły [...].

Ale przypomni sobie, zrobi... czuł to z pewnością. Co tylko, nie wiedział jeszcze dokładnie...

Później -

tak później sobie przypomni - ...

Tam.

Szedł więc.

Okrągłe oczy latarni i jakieś światła wypełzły z mroku, wtłoczyły mu się pod czaszkę i patrzą weń długo, długo... ${ }^{17}$

Światło latarni wybija zatem podmiot z poczucia spoistości, zabiera mu przekonanie o własnej koherencji. Animalizowane światło wyposażone zostaje także w zdolność patrzenia. Hiperestezja podmiotu Wroczyńskiego przyczynia się do możliwości przekroczenia granic podmiotu przez świat zewnętrzny. Światło latarni wnika w podmiot na dwu przynajmniej poziomach: psychicznym i cielesnym ${ }^{18}$. Rozbija w ten sposób każdą osłonę.

Na podobnej metaforze latarni-oczu zasadza się mniej, co prawda, skomplikowany wiersz Miriama, w którym czytamy:

${ }^{16}$ Por. analiza tego wiersza U. M. Pilch, Dylematy Galicjanina: Kraków czy Wiedeń. O poezji Ludwika Szczepańskiego [w:] Kraków i Galicja wobec przemian cywilizacyjnych (1866-1914). Studia i szkice, pod red. K. Fiołek, M. Stali, Kraków 2011.

17 J. Wrocz yń sk i, Poezje prozq, oprac. M. Stala (Biblioteka Poezji Młodej Polski), Kraków 1995, s. 127-129.

${ }_{18}$ Por. M. S ta la, Jawa obłqkana (o Janie Wroczyńskim), [w tomie:] J. W roc zy ń s ki, Poezjje prozq, dz. cyt., s. 21. 
O miejskie, wietrzne, pochmurne wieczory,

Gdy wiry prochów po kamieniach tańczą,

Mrok - latarnianych ócz błyska szarańczą,

Ulice zieją jak jaskiń otwory!

Samotnyś. Błądzisz. W wyobraźni chorej

Rój dziwnych widem myśli twoje niańczą:

Zdasz się sam sobie duszą wywoławczą

Od której pierzcha tłum w ucieczce skory.

I mroki z wolna w duszę twą się sączą,

Gaszą w niej wszystko, tłumią swą opończą,

I pustka wielka zalewa ci łono.

Nawet marzenia, które życie złocą,

Pierzchły jak ptaki. Z głową opuszczoną

Szepczesz bez myśli: „Po co wszystko? po co?”19

Na poziomie stylistycznym animizująca metafora oczu będzie pewnie jedynym elementem wspólnym. Analogiczny wydaje się jednak także antyurbanizm przebijający przez oba teksty. Skrajnie negatywna waloryzacja całej miejskiej przestrzeni jest tu ewidentna. Do jej uwypuklenia wykorzystuje się sztafaż natury w odzierających z bezpieczeństwa wcieleniach. Światło latarni pojmowane jest równie pejoratywnie, nie daje ono w najmniejszym stopniu poczucia bezpieczeństwa, uwypukla natomiast otaczający mrok, grozę ciemności i wreszcie poczucie skrajnego wyizolowania podmiotu. Co znamienne, atmosfera miejskiego wieczoru prowokuje finalne, nacechowane rezygnacją i podważające sens istnienia pytanie: „Po co wszystko? po co?”

Taka współzależność specyficznie eksponowanej miejskiej aury i nagromadzenia pytań o charakterze egzystencjalnym wydaje się znamienna dla młodopolskiej liryki. U Szczepańskiego tej korelacji sprzyja konstrukcja sonetowa. Wiersz Urok fal ciemnych również należy do wspomnianego już cyklu $Z$ sonetów wiedeńskich. Opis sytuacji lirycznej wprowadza finalne pytania retoryczne:

\footnotetext{
Doprawdy, sam się nieraz sobie dziwię, Czemu rad błądzę wśród nocy spóźnionej

Nad zbrzeżem rzek i stawam wpatrzony

W fal czarną roztocz, płynącą leniwie...

Świateł odbłyski lśnią na toni szkliwie,

Co z głuchym bryzgiem wstrząsa mostu trzony -

W krąg miasto w blasków łunie wre zamglonej -

Tu noc - i głębia czarna przeraźliwie.
}

${ }^{19}$ Z. Przes m y ck i [Miriam], Wybór poezji, wyb. i oprac. T. Walas (Biblioteka Poezji Młodej Polski), Kraków 1982, s. 98. 
I stoję wsparty na mostu poręczy,

I po tej fali, która głucho jęczy,

Wzrok mój się ślizga, z lękiem w głąb się wierci -

Cóż mnie tu trzyma? Świateł złote błyski?

Harmonia szumu? Fal głuche rozpryski?

Czy ciemna tajń i ciemny urok śmierci? -

[Urok fal ciemnych, z cyklu Z sonetów wiedeńskich, 124]

Podmiot liryczny dokonuje tu próby określenia własnego miejsca w świecie i własnej tożsamości, a także niepojętej dlań natury więzi łączącej go z miastem. Co znamienne, podmiot fascynują w mieście jakości o charakterze opozycyjnym, aczkolwiek wyraźna jest przewaga tych - powiedzielibyśmy - negatywnych. Obraz odbijających się w wodzie świateł ${ }^{20}$ wydobywa ciemność i grozę fali. Miasto postrzegane jest tu przede wszystkim jako przestrzeń witalności, oglądana z pewnego dystansu. To właśnie perspektywa oddalenia uwydatnia znikomość rozświetlonego miasta wobec zachwytu głębią. Najważniejszy dla podmiotu okazuje się zapośredniczony obraz miasta - a mianowicie odbicie jego odległych świateł w wodzie. Uwidacznia się tu, jak sądzę, potrzeba zespolenia dwóch relacji. Mianowicie: podmiot obserwujący odbicie miejskich świateł w wodzie - a zatem dostrzegający realizujące się poznanie - próbuje przeprowadzić identyczny proces. Ów proces rozbija jednak absolutna niemożność odróżnienia statusu ontologicznego rzeczywistości i rzeczywistości odbicia. Z tego właśnie powodu podmiot rozprasza się, co jest dodatkowo wyeksponowane w puentującym wiersz wyliczeniu pytań.

Fascynacja odbiciem miejskich świateł w wodzie zostaje bardzo mocno zaakcentowana w utworze Stanisława Miłaszewskiego ${ }^{21}$ Bulwary, gdzie w sposób niemal udosłowniony pojawia się potencjalność istnienia w sferze pomiędzy odbiciem a odbijanym:

\footnotetext{
Okna domostw rzucają świateł złote żmije w rzekę, co czarną wstęgą w głąb miasta się wrzyna, W toń dyskretną, spokojną dzieciątko niczyje może w tej chwili ciska zwiedziona dziewczyna.
}

${ }^{20}$ M.in. o narcystycznym przeglądaniu miast w wodzie zob. E. R e w e r s, Ekran miejski. Źródto - lustro - A Third-Order Simulation [w tomie:] Pisanie miasta. Czytanie miasta, pod red. A. Zeidler-Janiszewskiej (Studia Kulturoznawcze), Poznań 1997. Por. z innej perspektywy: A. Cz ab anow ska-Wróbel, W zwierciadłach jezior, „Ruch Literacki” 1987, z. 4-5; te jże, Wyobraźnia akwatyczna w poezji Młodej Polski, „Pamiętnik Literacki”, R. 78, 1987, z. 3.

${ }^{21} \mathrm{O}$ twórczości Miłaszewskiego, a także o wyłaniającym się z niej obrazie miasta - zob. A. Cz a b a n ow sk a - W róbe l, „Nieuchwytny gest myśli to mowa osobna...” O życiu i twórczości Stanisława Miłaszewskiego [w:] S. Miłas zew ski, Poezje, wstęp, wybór i oprac. A. Czabanowska-Wróbel (Biblioteka Poezji Młodej Polski), Kraków 2008. 


\begin{abstract}
Na miękkim piasku na dnie trupek bladolicy rad będzie światłu, co mu zaigra na twarzy... Nie wiedzą, czuwający przez noc samotnicy, że każdy z nich topielca po królewsku darzy. $[\ldots]$

Wtenczas mali topielcy zsiniali, skostniali chwytają w ręce świateł już nieliczne sznury i podnoszą się z wolna na powierzchnię fali, skąd ich płoszą dopiero pierwsze ranne kury ${ }^{22}$.
\end{abstract}

W utworze Szczepańskiego rozważania podmiotu dotyczą de facto jego indywidualnej autooceny, próby wyrażenia jego stosunku do miasta. U Miłaszewskiego natomiast opis sytuacji lirycznej odnosi się przede wszystkim do nastroju miejskiej nocy i zarazem do diagnozy tożsamości miasta w ogóle. Składa się na nią bowiem współistnienie sprzeczności absolutnych. To, co sugeruje poczucie zadomowienia i bezpieczeństwa, zderzone zostaje z nieszczęściem zabójstwa, rozpaczą śmierci. Mocnemu zaakcentowaniu podlega równocześnie opozycja między spokojem cnoty a nagannością moralną rozpusty. Niemniej jednak na plan pierwszy wysuwa się raczej nie ocena moralna jako taka, lecz próba określenia miasta równocześnie jako miejsca płodności i śmierci. Światło obarczone jest tu symboliką ambiwalentną - daje poczucie bezpieczeństwa, ale jednocześnie naraża miasto na jakąś niedookreśloną obecność ożywających „topielców zsiniałych", pośrednio zatem wywołuje lęk.

Atmosfera lęku wyłania się także z wiersza Ludwika Szczepańskiego zatytułowanego Miasto. Obecność światła służy tu (jak niemal we wszystkich cytowanych dotychczas utworach) wyolbrzymieniu otaczającej ciemności - a samo odbicie w powierzchni szyby wydobywa kryjącą się pod nim ciemność:

Jak tajemnicze labiryntu mury

Ulice leżą głuche i milczące,

A martwych okien tafle czarnoszklące

Chłoną latarni żółtych blask ponury.

Zda się, że sen cichymi wionął pióry

I uśpił mrocznych tych gmachów tysiące -

A krok mój echa rozbudza huczące

We mgle, co wolno osnuwa kontury.

I zda się, że już spokój spłynął smętny...

Lecz słuchaj, słuchaj: Chaos ten kamienny

Drży i wiecznymi życia bije tętny:

Marzeń rój wzlata ku gwieździe jutrzennej,

Przekleństwo syczy wśród bólu Gehenny

I rozkosz żarzy się w ciszy namiętnej.

[Miasto, 63]

${ }^{22}$ S. Miłaszewski, Poezje, dz. cyt., s. 81. 
Głównym elementem nastrojotwórczym jest w tym tekście wszechobecna, pochłaniająca cisza, uwypuklająca z jednej strony niepokojący odgłos kroków podmiotu, z drugiej umożliwiająca usłyszenie wewnętrznego tętna życia ${ }^{23}$. Z ciszą współgra ciemność, która ponownie na zasadzie opozycji uwydatnia odbicie światła. Co istotne, światło to, określane jako „latarni żółtych blask ponury”, nie jest w najmniejszym stopniu waloryzowane pozytywnie, a dodatkowo zostaje pochłonięte przez ciemność. Innego rodzaju jasność pojawia się natomiast w puencie utworu. Rozpiętość symboliczna ostatniej strofy oscyluje tu od symboliki gwiazdy zarannej, przez ból Gehenny, aż po żar rozkoszy. Niepokojący, martwy blask latarni ustępuje zatem miejsca chaosowi, wybuchowi energii życiowej, witalnemu potencjałowi kumulującemu w sobie zarówno to, co pozytywne, jak i negatywne.

Jeszcze wyraźniejszy zachwyt witalnością wielkiego miasta uwidacznia się w tekście Piosenka moja, gdzie między innymi padają słowa:

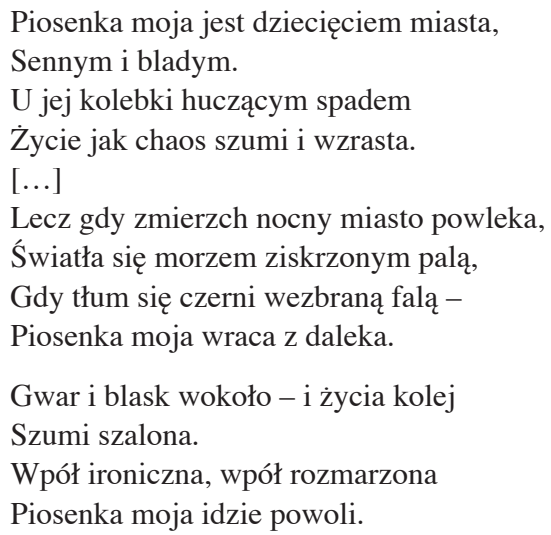

[Piosenka moja, 91]

Pejzaż wielkiego miasta i jego ogrom jest tu budowany właśnie w oparciu o światło. To ono ma być jednym z najbardziej wyrazistych przejawów intensywności życia. Nieco zdystansowana postawa podmiotu, który określa piosenkę jako ,ironiczną” i „rozmarzoną”, uwidacznia się także w przekornie powolnym chodzeniu, we flânerie $\mathrm{z}$ całym jej bagażem znaczeniowym ${ }^{24}$. Ale nawet takie

${ }^{23}$ Por. interpretacja U. M. Pilch, Dylematy Galicjanina..., dz. cyt.

${ }^{24}$ Odsyłam tu do znanych tekstów: W. B enja min, Pasaże, pod. red. R. Tiedemann, przeł. I. Kania, posłowiem opatrzył Z. Baumann, Kraków 2006; H. Paetzold, Polityka przechadzki, tłum. E. Mikina [w tomie:] Formy estetyzacji przestrzeni publicznej, pod red. J. S. Wojciechowskiego i A. Zeidler-Janiszewskiej; H. Paetzold, Doświadczanie architektury miasta. Polityka przechadzki w duchu Waltera Benjamina [w:] Co to jest architektura, red. A. Budak, t. 2, Kraków 2008; B. B r z o zo w s k a, Spadkobiercy flâneura. Spacer jako twórczość kulturowa-współczesna reprezentacja (Sztuka/Media/Kultura), Łódź 2009; B. Fry d ry c za k, Okiem przechodnia: ulica jako przestrzeń estetyczna [w:] tamże; A. Ze i d le r-J a n i z ze w sk a, Dryfujq̨cy flâneur, czyli o sytuacjonistycznym doświadczaniu miejskiej przestrzeni [w tomie:] Przestrzeń, filozofia, architektura, 
kontrastowe wyróżnienie z przestrzeni przepełnionego siłami witalnymi, dynamicznego miasta - nie niweluje zależności podmiotu od miejskiej energii. Tę zależność raczej wyolbrzymia.

Inaczej na tym tle wybrzmiewa utwór Władysława Orkana o incipicie Gdzież, Warszawo milczqca... Życie nocne ma tu stanowić podstawę oceny miasta. W tym zaangażowanym społecznie i politycznie, opublikowanym w styczniu 1906, opisującym świt rewolucji wierszu padają słowa:

Gdzież, Warszawo milcząca,

Twoje wczorajsze słońca?

Twe sezono-zimowe Oriony?...

Tak przejasno świeciły,

Tak widne od nich były,

Twe przegędźbne, przegłośne salony -

Czyżby ich blask zjawiony

Był złudny, pożyczony,

I noc tylko ich zjaśnień przyczyną?

A skoro świt wybrzasnął,

Ich blask skradziony zgasnął,

Jak gwiazd lica, gdy świtać poczyna? -

$[\ldots]$

Warszawa śpi...

Pogasły nocne jej słońca,

Pomilkła gędźba gędząca,

Dreszczem jeno wstrząsa ją świt zimny...

A Ty, Warszawo-Ulico, wstająca

W świtania krwi,

Nowe zapalasz słońca

I nowe rodzisz hymny!... ${ }^{25}$

Symbolika świateł stolicy jest tu rozłożona na kilku poziomach. Rozwój miasta, a przede wszystkim właśnie jego światło ma tu stanowić znak pozoru, blichtru, powierzchownej wspaniałości i pustej rozrywki. Mocno zaakcentowana sztuczność miejskiego światła przeciwstawiona zostaje obarczonemu nawarstwiającymi się, bardzo pozytywnie waloryzowanymi znaczeniami świtu i słońca jako ekwiwalentów „Warszawy-Ulicy”26.

red. E. Rewers, Studia kulturoznawcze, t. 12, Poznań 1999. Zob. też G. Simme1, Mentalność mieszkańców wielkich miast [w:] Most i drzwi. Wybór esejów, przeł. M. Łukasiewicz, Warszawa 2006.

${ }^{25}$ W. Orkan, Poezje zebrane, wiersze zebrał, tekst opracował i komentarzem opatrzył J. Kwiatkowski, Kraków 1968, t. 1, s. 317-318; pierwodruk: „Tydzień”, Lwów 1906, nr 1 (6.I). Zob. Komentarz. Nota wydawcy, 461.

${ }^{26}$ Bywają także i utwory o charakterze anegdotycznym, wyraźnie zaangażowane społecznie, gdzie na plan pierwszy wybija się wielowymiarowa (także moralna) nędza miasta obnażana przez światło: J. K a s prow i c z, Światło boże: „Światło boże padło na ulicę,/ Z całej gęby roześmiał się 
Cykliczność następstwa dnia i nocy staje się elementem nastrojotwórczym w cyklu Edwarda Leszczyńskiego Kawiarnia, a zwłaszcza w ostatnim sonecie:
Jest chwila, gdy się z wolna kawiarnia opróżnia, że słońca elektryczne mglą się tajemniczo
i jak lampy grobowe zwisają i syczą, a kształt każdy w niepewne linie się rozluźnia.
Senność jakaś leniwa godzinę opóźnia, a przez okno nieśmiało swą twarzą dziewiczą świt zagląda i pełznie ku zbladłym obliczom, kędy jeszcze frazesów wre zajadła kuźnia.
Drzwi zamknięto. W ulicy jeszcze mrok się spiętrza, jakby w mglistym przyćmieniu teatralnej rampy muśnięty dreszczem wschodu - aż z kawiarni wnętrza
śmieje się poprzez szyby jakiś półton lampy tym uśmiechem szyderczym, martwym trupiej czaszki, w którą ktoś tlący węglik włożył dla igraszki ${ }^{27}$.

Miejski świt ujmowany jest tu na innej zasadzie niż w dotychczas analizowanych utworach, a mianowicie z perspektywy wnętrza. Poświata, którą roztacza kawiarnia, sztuczność elektrycznego światła obnaża zafałszowanie i martwotę całego miejsca. Ta martwota zostaje zasugerowana poprzez porównanie lamp elektrycznych (metaforycznie nazwanych tu słońcami) do lamp grobowych. Zatracanie ostrości konturów, rozmywanie kształtów staje się jeszcze jednym symptomem poddawania w wątpliwość jakości statusu egzystencjalnego tego miejsca. Świt, który może obnażyć pozór, jest jeszcze zbyt słaby, by zniwelować to, co negatywne, stare, zużyte, nieświeże. Na te wszystkie określenia zezwala personifikujące przyporządkowanie porankowi dziewiczej twarzy. Spotęgowanie, za pomocą typu oświetlenia, efektu zamkniętego wnętrza bardzo mocno hiperbolizuje sztuczność zarówno miejsca, jak i sytuacji.

Najjaskrawiej zło miasta ${ }^{28}$ przedstawione jest w poemacie Stanisława Brzozowskiego Teodor Dostojewski. Z mroków duszy rosyjskiej ${ }^{29}$ :

dzionek” [45]; Hajs' marony: „Pogaszono latarnie dokoła,/ Miasto w senną popadło już ciszę,/ Tylko z rogu głos ochrypły woła: / Hajs’ marony! hajse! hajse! frisze! [46]; Venus vulgivaga: „Światła płoną na ulicach miasta;/ Tłum próżniaków, jak rzeka się wzmaga,/ A wśród niego gałgankami szasta/ Wyuzdana Venus vulgivaga" [47]; J. K a s prow ic z, Pisma zebrane, t. 3, cz. I.

${ }^{27}$ E. Le s zc zy ń s ki, Wybór poezji, oprac. H. Filipkowska, (Biblioteka Poezji Młodej Polski), Kraków 1988, s. 231.

${ }^{28}$ Negatywny obraz Petersburga ma swą mocną tradycję w literaturze polskiej.

${ }^{29} \mathrm{Za}$ cenne przypomnienie winna jestem podziękowania prof. dr. hab. Wojciechowi Gutowskiemu. 


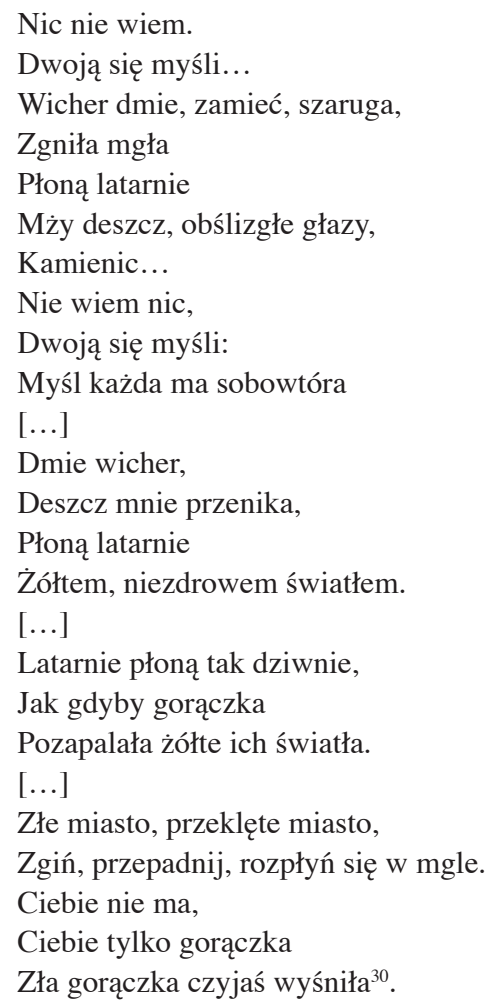

Można powiedzieć, że nierealny charakter tej przestrzeni posunięty został do skrajności. Otóż ohyda miasta hiperbolizowana przez malignę, obłęd, chorobliwość światła latarni staje się tak absurdalnie przytłaczjąca, że przestaje być rzeczywista. Jedyną drogą ratunku są rozpaczliwe performatywy „zgiń” i deklaracje "Ciebie nie ma". Miasto, które powoduje gorączkowe zwidy, samo ma okazać się omamem.

Jeśli zatem na przykład u Brzozowskiego, Leszczyńskiego krajobraz miejski budzi odrazę, a u Szczepańskiego grozę i ekscytację, to innego rodzaju emocje ewokowane są w poezji Aleksandra Szczęsnego. Również on buduje aurę niepokoju w oparciu o domykający charakter światła latarni i fałszywość odbić. Wydaje się jednak, że w ogólnym wymiarze waloryzacja światła miejskiego jest wartościowana dodatnio. Jednym z lejtmotywów tej poezji jest obraz światła (nie tylko sztucznego, ale też słonecznego) odbijającego się w szybie okiennej ${ }^{31}$.

${ }^{30}$ S. B r zo zo w s k i, Teodor Dostojewski. Z mroków duszy rosyjskiej, Kraków 1906, s. 58-63.

31 Por. uwagi [w:] A. La m, Aleksander Szczęsny [w tomie:] Obraz literatury polskiej XIX i XX wieku. Literatura okresu Młodej Polski, t. 1, red. K. Wyka, A. Hutnikiewicz, M. Puchalska, Warszawa 1968, s. 606. 
Głuchych ulicznych kroków utrudzone wrzawą, Szyby od słońca złote roją nocy ciemnię,

Nad równiną podmiejską błyskając daremnie,

Zanim się ciężka kula w otchłań stoczy krwawą.

$[111]^{32}$

Utwór Szyby od słońca złote uzmysławia szczególną skłonność Szczęsnego do opisywania miasta w momencie przejściowym - w chwili zmierzchu. To właśnie dzięki oświetleniu zachodzącego słońca szyby nabierają blasku. Określenia o charakterze personifikującym sugerują potrzebę odpoczynku. Zdanie „roją nocy ciemnię" wprowadza element niepokoju i wskazuje natychmiast, że światło słońca podwójnie zafałszowuje ogląd świata; w pozornie radosnym obrazie zaciera się świadomość nadchodzącej nocy, a za sprawą odbicia zataja się ciemność zamkniętych wnętrz. Niewątpliwa uroda tego momentu zostaje jednak najmocniej podważona w ekspresjonizującym opisie zachodu słońca.

Fascynacja porą zmierzchu i jej wpływem na wizerunek miasta uwidacznia się także w wierszu Zachód:

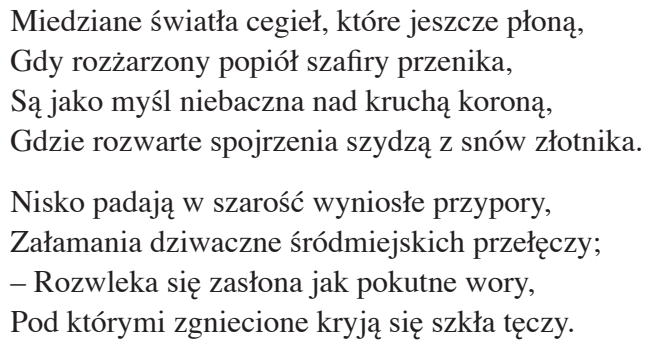

Miasto opisywane jest tu w kategoriach natury ${ }^{33}$. Nie chodzi, oczywiście, o kwestię naturalnego oświetlenia słonecznego, ale o język deskrypcji, w którym wykorzystuje się metaforykę krajobrazu górskiego. Inaczej niż w poprzednim tekście, nie ma wprowadzonego tu elementu jawnej obecności człowieka, nacisk pada bowiem raczej na oddanie nastroju chwili jako takiej. Kumulacja światła, blasku i żaru (zbudowana za pomocą inicjalnej metafory) w miejskich murach potraktowana jest jako zjawisko tyle piękne, ile krótkotrwałe i złudne. Ulotność właśnie zostaje wydobyta w porównaniu z myślą, opisywaną skądinąd znów za pomocą metafory. Określenie „sen złotnika” wskazuje także na wykroczenie

${ }^{32}$ A. Szczęs ny, Poezje wybrane, oprac. R. Okulicz-Kozaryn, M. Ignaszak, wstęp R. Okulicz-Kozaryn (Biblioteka Poezji Młodej Polski), Kraków 2000. Liczby w nawiasach oznaczają numer strony z tego wydania.

${ }^{33}$ Dla porównania warto przytoczyć fragmenty utworu Stanisława Miłaszewskiego Pogoń: „Ku wzgórzom dachów miejskich, gdzie pod wieczór dymi / knieja kominów mnóstwem czarnych pióropuszy, / Żądze i myśli moje porwał pęd olbrzymi. / I zostałem z bezludną duszą czy bez duszy”. S. Miłas zew ski, dz. cyt., s. 99. 
poza realność. Druga zwrotka przynosi już ewidentny obraz zapadania zmroku - kolor ustępuje szarości (zapowiadanej skądinąd przez wcześniej pojawiające się popioły). Puentujące utwór "szkła tęczy” mają znaczenie co najmniej dwoiste - sugerują zatem przytłumienie i zamieranie blasku, ale równocześnie przecież budują aurę nadziei na nastanie nowego dnia i nowego światła.

Najbardziej fascynuje Szczęsnego moment przełamywania się światła; albo inaczej: moment, w którym światło stanowi jedno ze znamion przełomu. W wierszu Pierwszemu śniegowi chwilę zmierzchu wyznacza między innymi oczekiwanie na zapalenie latarni:

Wiatr przewiał wskroś ulice i w prędkim wieczorze,

Nim jeszcze latarniane ogniki zapłoną,

$\mathrm{Z}$ wysoka, kędy umęczone oczy toną,

Miękkich bezgłośnych płatków polatuje morze.

Gaszenie ulicznego oświetlenia natomiast pozwala na zaakcentowanie poran$\mathrm{ka}^{34}$. W wierszu W przedporannym zaduchu czytamy zatem:

\begin{abstract}
Wiedz, że po mieście nuda włóczy się nad ranem,
Czujna jak mdłych latarni pochylone szyje,

Więc cóż, że noc konając serce ci przeszyje

Szczyptą gwiazd, spadających za jej karawanem.

$[\ldots]$

Dzień wytryśnie, a miasto lepkie daje rady;

- Potrącając skulonych błędu latarników,

W moim śmiechu otrząsać wstaniesz kurz z pomników,

Nim znów cię przeszyje gwiazdek opył blady.
\end{abstract}

[W przedporannym zaduchu..., 127]

Ujawnia się tu co najmniej kilka zupełnie zasadniczych elementów nastrojowości całej epoki: flanerowanie, nuda, wyobcowanie, ale też silne uzależnienie od tego świata i wreszcie potrzeba zadomowienia. Noc dobiega końca, dominuje znużenie połączone z poczuciem swoistej utraty. Nadchodzący świt niweluje światło latarni, ale przede wszystkim odbiera blask gwiazdom, które zdają się tu symbolizować prawdy najwyższe, inspirację twórczą, ale także jakąś nocną zafałszowaną błazenadę. Wszystko zatem to, co było waloryzowane pozytywnie, wytraca ten swój wymiar; okazuje się explicite ujawnionym błędem ${ }^{35}$.

${ }^{34}$ Ujawnia się tu także szczególnej wagi rola postaci latarników dla kształtowania XIX-wiecznej i późniejszej wyobraźni. Dla przykładu przywołać można chociażby niezwykle znamienne pod tym względem opowiadanie Bolesława Pru s a zatytułowane Cienie.

35 Szczęsny łączy w swojej wizji miasta rozmaite typy oświetlenia, eksponując także rozgwieżdżone niebo. (O gwiazdach w młodopolskiej poezji już sporo pisano). Bywa przecież i tak, np. u Jerzego Żuławskiego w sonecie Bern w nocy, że jedynym oświetleniem jest księżyc (por. analizy obecności księżyca w badaniach M. Stali): „Księżyc w wąską ulicę otuloną cieniem / wpadł 
Wskazana przeze mnie przejściowość, którą Szczęsny eksponuje za pomocą następujących w czasie przemian światła - w cyklu Obojętny ujawnia się również na poziomie przestrzeni:

- Ciemna łuna wytryska miastom pełnym krzyku, Wody mostom zwierzyły syczące westchnienia.

[...]

Ale zanim się śpiący hałas roznamiętni,

W groźną ciszę, łaskawą na błazeństwa szczodre,

- Pójdźmy ujrzeć latarnie, szyby cicho-modre,

Gdzie rybacy podwodni śpią łowom niechętni.

[Obojętny II, 145]

Tak-em pojął latarnie i szyb cicho modry

Płochliwych pełen cieniów zbiornik kruchy, szklany,

Jedna noc, gdy już dymi zbrudzony świt ranny,

Czyż być może dziwniejsza w tajemnicy szczodrej.

[...]

Przecieram zaschłe oczy i ku zaspom śnieżnym,

Polatującym równie jak stargane włosy,

Odchodzę niosąc wiosnę tak lśniących bez rosy,

Jako gwiezdna koronka niebiosom bezbrzeżnym

[Obojętny IV, 149]

W pierwszym fragmencie światło latarni przede wszystkim sprzyja efektowi emocjonalnego uspokojenia. Efekt ten zostaje wyeksponowany przez opis miejskich dźwięków, które konstytuuje „krzyk”, „syczące westchnienia”, „,hałas". Zbiór tych określeń zostaje zderzony z ciszą opatrzoną, co prawda, epitetem „groźna”, ale przynoszącą tu wrażenie bezpieczeństwa czy raczej ukojenia. W drugim natomiast fragmencie moment spójnie łączący sprzeczne jakości sztucznego światła i szarzejącego świtu powiązany zostaje z przełomem zupełnie innego rodzaju. Ów graniczny moment jest paralelny wobec aktu przekroczenia granicy miasta i transgresji w stronę natury.

Wszystkie dotychczas wspomniane utwory Szczęsnego łączy szczególny nastrój wyciszenia, który wykracza poza negatywną lub pozytywną waloryzację miasta i jego światła. Najbardziej charakterystyczny pod tym względem wydaje się bodaj czy nie jeden z ciekawszych utworów Szczęsnego, Opowiadanie:

i zajrzał pod arkad łuki [...] Księżyc miasto zalewa promienistym srebrem - / cisza - tylko uliczne źródła i fontanny / pluszczą, szemrzą i skrzą się, jęk wydając szklanny”. J. Żu ła w ski, Wiersze wybrane, wybrał i wstępem opatrzył M. Jastrun, Warszawa 1965, s. 30. W utworze Marii Mark ow ski ej Tobie, Ulico! księżyc zostaje metaforycznie zestawiony z lampą: ,[...] W krwawych oparach blada twarz miesiąca / wschodzi nocami i żyjące straszy, niby tragiczna lampa, gorejąca / nad jakąś wieków trumną... [...]" M. Markow s ka, Poezje, Kraków (brak daty) - por. Poetki przełomu XIX i XX wieku. Antologia, oprac. zespół pod red. J. Zacharskiej, Białystok 2000 - tu w haśle poświęconym Markowskiej opracowanym przez A. Wydrycką - data 1909. 
Po pustych miastach - włóczą się globy słońc, w płomieni swoich złocie; śpij, słodko myśląc o włóczęgach świateł. - [...]

W krzywych uliczkach miast, gdzie się rozrasta błoto, włóczą się globy słońca, w płomieni swych złocie. -

Po co się włóczą tam słoneczni ci pijacy?

Czy jakieś buntu pieśnie wzniecić chcą w zapadłych szybach?

Śpij słodko; - słońca muszą włóczyć się po ziemi -

- aby nie popadł w zbytnią wzgardę cień - od starych domów; [...]

Śpij słodko; - bowiem nie wiesz, ma dziecino mała, że te włóczęgi słońc, jako i twierdze cieniów, istnieniem sobie wzajem dają życie - a muszą żyć tak słońca, jak i cienie.

- Proś we śnie bogów o inaczej wklęsłe lustro prawdy - [69-70]

Ten fragment prozy poetyckiej stoi na przeciwległym biegunie w stosunku do cytowanego na początku niniejszego artykułu utworu Micińskiego. Dominuje tu - wbrew ogólnym tendencjom i nawet wbrew nieco patetycznej aurze - nastrój spowolnienia, uspokojenia. Nie sugeruje on jednak - tak przecież częstej w innych tekstach - stagnacji. Ten nastrój wywoływany jest przede wszystkim przez kojące stwierdzenie: „śsij słodko”. Najważniejszym elementem konstruowanej tu przestrzeni okazują się „globy słońc - włóczęgi świateł”36. Personifikowane światła kumulują w sobie i blask słońca, i blask latarni. A wreszcie także wartość myśli ludzkiej. Światła te, choć, jak to często bywa w tekstach młodopolskich (ale i nie tylko), obnażają nędzę i biedotę miasta, dają jednocześnie poczucie bezpiecznej i zarazem radosnej nadziei. Szczególną wagę ma tu także wspomniane określenie „włóczą się”, które z jednej strony sugeruje przypadkowość ruchu, bezcelowość wędrówki, ale z drugiej okazuje się w tekście warunkiem uzasadnionego kształtu świata.

Ambiwalentna symbolika światła w liryce Młodej Polski oscyluje od negatywnie nacechowanego światła martwoty, przez niepokojący blask obnażający i hiperbolizujący ciemność, wreszcie po zachwyt energią życiową przejawiającą się w miejskiej feerii świateł, a nawet po uczucie ukojenia i zadomowienia. Światło stwarza efekt wielkomiejskości i w takim sprzężeniu zwrotnym, to znaczy jako pośrednio odpowiedzialne za wielkomiejskość, jest intepretowane. Najczęściej też miasto w liryce ujmowane jest w kategoriach tyle groźnych, ile znanych. Język obrazowania wpisuje się bowiem często w sposób pokrewny obrazowaniu i pojmowaniu natury, w pewnym sensie bez względu na specyfikę przestrzeni miejskiej, a nawet jej oświetlenia

${ }^{36}$ Por. także fragment wiersza Ballada o kochance: „Ogromne słońca błądzą po krzywych ulicach, / - Sądy boże się wsparły na dymnych gromnicach. // A kochanka ma nigdy do mnie nie powróci, / - Ze snu rozłąki jej żaden uścisk nie ocuci”, s. 82. 
Częstsze poczucie wyobcowania, świadomość bycia obserwowanym wynika ze zogniskowania przestrzeni miasta w podmiocie i przyczynia się do przerażenia własną jednostkowością, a zarazem do odarcia z indywidualności. Światło prowokuje próby autooceny. Rozpoznane światło miasta zarówno obnaża trupiość, jak i wydobywa niezwykłą wręcz siłę witalności. Te biegunowe cechy prowadzą do dostrzeżenia w wirze życia sztuczności, blichtru, ale prowadzą także do uznania siły ludzkiego osiągnięcia:

\section{Zgłębił dno morza, przeciął ziem przestrzenie Jak płótna modre, zsunął widnokręgi, \\ Rzucił w noc światła, jaśniejsze niż gwiazdy, Wyprzedził wichry na żelaznych zwierzach \\ Dyszących ogniem ${ }^{37}$.}

Rzadko jednak w liryce Młodej Polski, poza pewnymi wyjątkami, światło miasta traktowane jest jako triumf cywilizacji. Widać tu raczej łączenie poczucia przesytu, schyłkowości, nudy, wreszcie grozy śmierci i stagnacji z fascynacją dynamiką, witalnością i tempem miejskiego życia. Przytoczone literackie przykłady stanowią oczywiście wybór, niemniej jednak reprezentatywny. Wielowymiarowa ekscytacja światłem miasta oscyluje wokół estetyki wzniosłości - aczkolwiek, zwłaszcza w przypadku młodszych twórców, zapowiada już przemiany spod znaku międzywojnia.

W wierszach młodopolskich światło latarni najczęściej eksponuje sztuczność i zarazem nierealność przestrzeni miejskiej. Przepełniony ogromem oczekiwań podmiot nie może i zarazem nie chce zbudować wobec niej dystansu. Jest uwięziony pomiędzy fałszywością odbić i stanem absolutnego przenicowania przez światło miejskie.

\section{Urszula M. Pilch}

\section{THE LIGHTS OF A BIG CITY IN THE POETRY OF THE YOUNG POLAND MOVEMENT}

Summary

This article concerns itself with the motif of light - not only depictions of street lights but also evocations of the urban radiance (or its lack) - in the work of Tadeusz Miciński, Ludwik Szczepański, Jan Wroczyński, Zenon Przesmycki, Stanisław Miłaszewski, Władysław Orkan, Edward Leszczyński, Stanisław Brzozowski, Aleksander Szczęsny and Leopold Staff. It appears that all of them used the imagery of light to construct and position their poetic personas. It is the glaring light that is best suited to underline surfeit, decadence, ennui, the horror of death and the fascinating, restless urban dynamic frozen to sudden stillness. It is that type of light that exposes both the artificiality and unreality of the urban space and deprives the poetic persona of his ability of stand away from it. He is caught up in the false reflections and the penetrating beam of the urban light.

${ }^{37}$ L. Staff, Adam [w:] teg o ż, Poez.je zebrane, t. 1, Warszawa 1967, s. 1124. 